\title{
AGE OF CERTAIN PLANT-BEARING BEDS AND ASSOCIATED MARINE FORMATIONS IN SOUTH AMERICA ${ }^{1}$
}

BY EDWARD W. BERRY

(Read before the Paleontological Society December 31, 1917)

CONTENTS

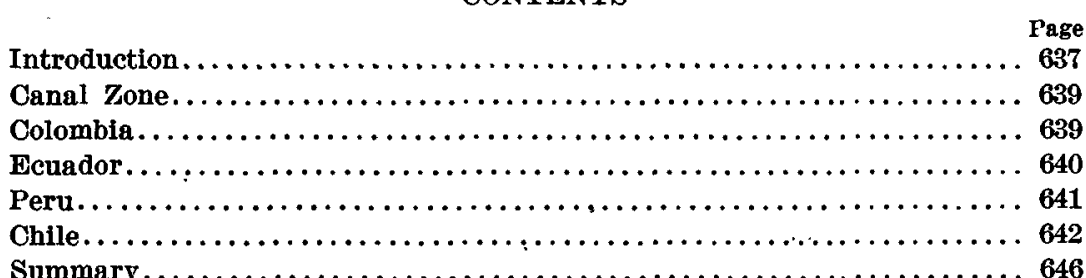

\section{INTRODUCTION}

Tertiary sediments are found at scattered localities throughout the continent of South America, and the Argentina Tertiaries in particular have been extensively exploited in connection with the study of the varied vertebrate fossils which they contain. Marine Tertiary deposits are found in the latter region as well as around the margin of the Brazilian plateau; they are widely distributed along the west coast, and in the Andean region they are scattered from Colombia and Venezuela to Tierra del Fuego and beyond. Our knowledge of all of these is very fragmentary and is limited for the most part to incidental descriptions in connection with the study of the contained floras or faunas rather than on detailed areal and stratigraphic work.

In the present brief contribution the discussion is centered on the prePliocene Tertiary of the Andean region and of the west coast, since the data at hand seem sufficient for tentative correlations and it is the beds in this part of the continent that may be expected eventually to uniavel the geological history of the Andean chains. In the Andean region itself

\footnotetext{
1 Manuscript received by the Secretary of the Society August 22, 1918.
} 


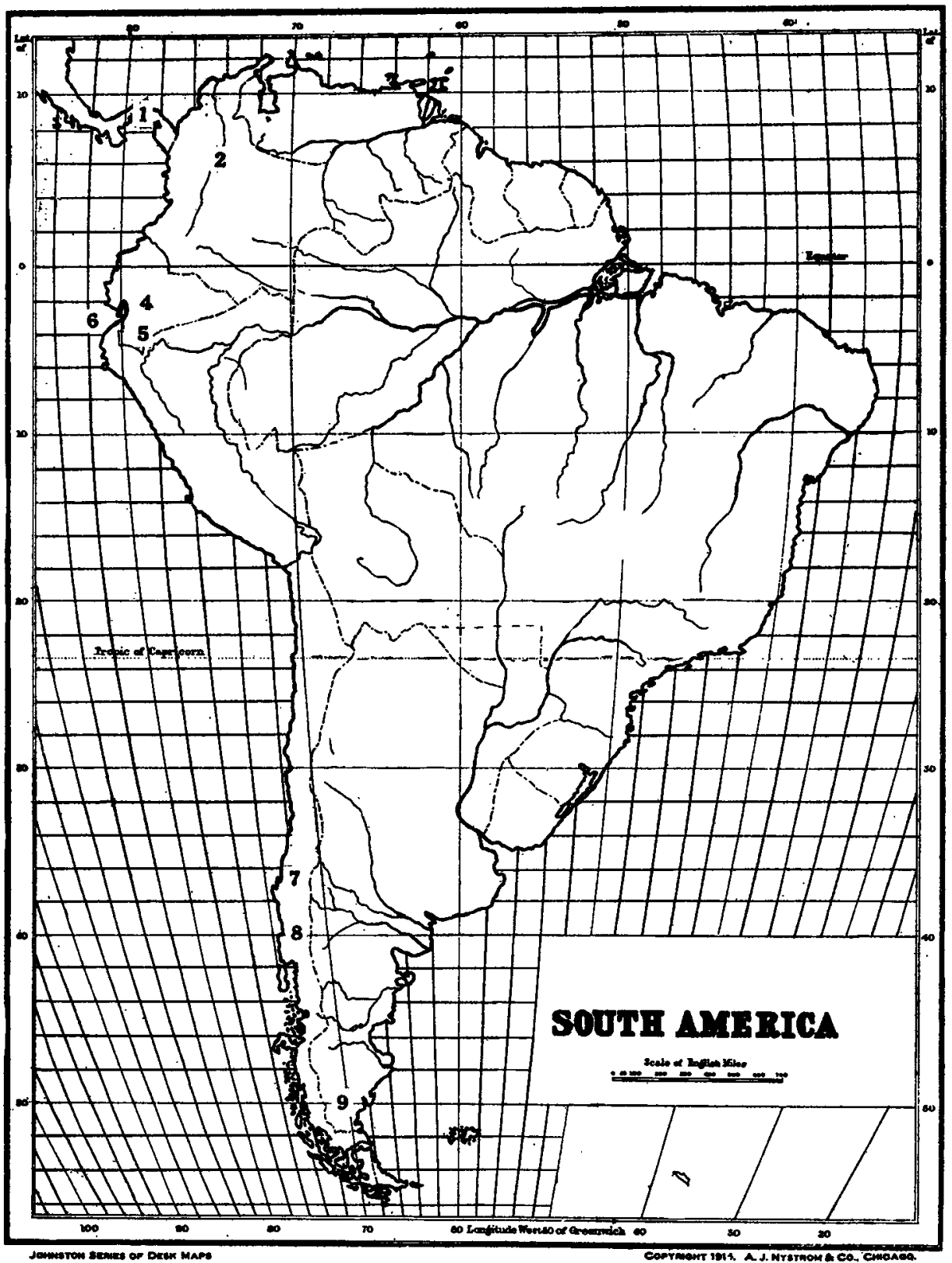

Figuru 1.-Map of South America

Showing distribution of lower Miocene plant beds: 1, Canal Zone; 2, Santa Ana, Rio Magdalena Valley, Colombia; 3, near Buga, Rlo Cauca Valley, Colombia; 4, Tablayacu, Rio Jubones basin, Ecuador; 5, Loja basin, Ecuador; 6, near Tumbez, Peru; 7, Coronel, Chlle; 8 , Navidad beds, Chlle; 9, Patagonian beds, Argentina. 
certain localities are not mentioned, either because of the absence of fossil plants or for the reason that no definite opinion seemed permissible. The principal localities that are referred to are shown on the accompanying sketch map (figure 1) and will be discussed in regular order.

\section{Canal Zone}

The described section in the Canal Zone (locality number 1) is of the greatest importance in this connection, for while it is not a part of the Andean system, the Canal Zone, because of its nearness to South America and the rather definite correlation of its Tertiary formations, offers a convenient standard for comparison. Moreover, the geological history of the Isthmian region has a direct bearing on the facies of the marine faunas of the west coast and the history of the terrestrial floras that have entered South America from North America during those times that the Isthmus was above the sea. The section need not be quoted in the present connection, since the formations have recently been described by MacDonald, ${ }^{2}$ and their correlation with the Tertiaries of our Southern States, the Antilles, and Europe has been given in an important paper by Vaughan. ${ }^{3}$

The geological history of the Isthmus arrived at by Vaughan indicates that the region was emerged, and that there was no interoceanic connection across it during the whole of the Cretaceous and the earlier half of the Eocene, and that there was free communication between the two oceans during the Upper Eocene, Oligocene, and Lower Miocene. This has an important bearing on the history of the fioras and faunas of the region to the southward, as I have already mentioned, and it will develop on subsequent pages that this history corresponds with the history of the opposite end of South America, and also accounts for the Mediterranean elements found in the Tertiary marine faunas of Peru and Chile.

\section{CoLombia}

Fossil plants have been described from two localities in Colombia. These are Santa Ana (locality number 2), along the western margin of the Rio Magdalena Valley, and near Buga (locality number 3), in the Rio Cauca Valley. The first is between the eastern and central and the second between the central and western Andean chains. At both locali-

\footnotetext{
2 D. F. MacDonald : U. S. Bureau of Mines, Bull. 86, 1915; U. S. Natl. Mus. Bull. 103 (in press).

\&. W. Vaughan : U. S. Natl. Mus. Bull, 103 (in press).
} 
ties the fossil plants occur in tuffs, ${ }^{4}$ and there is no evidence of contemporaneous or subsequent marine deposits in this general region, although it must be constantly borne in mind that the area has been very imperfectly explored. The flora found near Buga is very limited in extent, and while it is probably the same or very nearly the same age as that found in the Rio Magdalena Valley, this can not be demonstrated. The flora of Rio Magdalena Valley comprises 35 species, well distributed among the natural orders. It is clearly a mesophytic tropical flora and it contains numerous elements that are strictly South American in existing floras. Among these are the genera Stenospermatium, Goeppertia, Acrodiclidium, Condaminea, Vochysia, Trigonia, etcetera. Nine of the Santa Ana species have an outside distribution. Seven of these have been found in Peru, two in Ecuador, and two in Chile. These afford a basis for tentative correlation which will be referred to in a subsequent paragraph, since the basis for all of the proposed correlations rests on various collateral lines of evidence rather than on direct individual comparisons.

Stille ${ }^{5}$ has described coarse valley filling in the Rio Magdalena Valley which he calls the Honda beds. These may possibly be of the same age as the plant-bearing tuffs, but they are probably much younger and may be considered to represent upper Miocene or Pleistocene continental sediments or possibly both.

\section{ECUADOR}

Fossil plants are known from two principal localities in Ecuador. These are Tablayacu (locality number 4), in the Rio Jubones basin, and several localities in the Loja basin (locality number 5). Only three species are recorded from the former, but one of these is also found in the Loja basin, and it therefore seems probable that the two deposits are of the same age. The occurrence of lignites and associated leaf impressions in the Loja basin has been known for a generation or longer. ${ }^{6}$ Engelhardt ${ }^{\gamma}$ has described 40 species of fossil plants from this locality, but the age of the beds has never been fixed beyond that they were Tertiary. One of the Loja plants occurs in the Colombia deposits, another in the Caimito formation of the Canal Zone, three are found in Chile, and one in Peru. The flora, judged by modern standards, is distinctly South American in its facies, with species of Arthante, Hieronymia, Cam-

\footnotetext{
H. Engelhardt : Abh. Senck. Naturf. Gesell., Band 19, 1895.

$\mathrm{H}$. Stille: Geologische Studien im Geblete des Rio Magdalena. von Koenen Festschrift, 1907, pp. 277-358.

T. Wolf and G. Rath : Zeits. Deutsch. Geol. Gesell., Bd. 28, 1876, pp. 391-393.

'H. Engelhardt: Abh. Senck. Naturf. Gesell., Bd. 19, 1895.
} 
phoromœa, Luhea, Banisteria, Tapiria, Vochysia, and other South American types, and denotes a mesophytic tropical environment.

\section{PeRU}

From near Tumbez (locality number 6), on the coast of Peru, I have recently described a small flora of 14 species, ${ }^{8}$ of which several are only tentatively identified because of the fragmentary nature of the material. Seven of these species are common to the Tertiary of Colombia, one is found in the Culebra, Gatun, and Caimito formations of the Canal Zone, one in the Loja basin of Ecuador, one in Chile, and another is close to if not identical with a Chilean form. This flora denotes very different climatic conditions from those that prevail at the present time in this semidesert coastal region.

The plant localities in Colombia and Ecuador represent continental cleposits and lack marine faunas. In the case of Tumbez, however, we are dealing with lagoonal deposits intercalated in a marine fossiliferous series, so that the evidence of the flora can be checked by a certain amount of faunal evidence. The general section of the Tertiary of the coastal region of Peru is segregated by Grzybowski ${ }^{9}$ into the following units, to which he assigns the ages as given below:

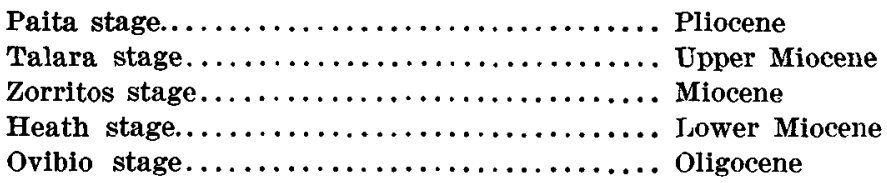

The fossil plants come from the Heath stage. The small fauna found in the associated beds of this stage comprise 19 species, representing the genera Arca, Turritella, Pyrula, Puncturella, Ostrea, Venus, Cytherea, Cardium, Lutraria, Dosinia, Leda, and Lucina. Venus münsteri and Lutraria vetula are common to the Navidad beds of Chile, Cytherea planivieta occurs in the Bowden marl of Jamaica, and Turritella altilirata in the Gatun formation of the Canal Zone. The genera Lutraria, Ostrea, and Cardium have closely related species in the Navidad beds of Chile, and Dosinia is represented by a closely related species in the Miocene of the Island of Trinidad. The Bowden marl has been shown to be of Burdigalian age by Woodring, while the Gatun formation, according to Douvillé and Vaughan, represents both Burdigalian and Helvetian. The

\footnotetext{
8 E. W. Berry : U. S. National Museum, Proc., vol. 55, 1919, pp. 279-294, pls. 14-17.

'J. Grzybowski : Die Tertiärablagerungen des nördlichen Peru und ihre Molluskenfauna. Neues Jahrb. Bell., Bd. 12, 1899, pp. 610-664, pls. 15-20.
} 
fossil plants associated with the foregoing mollusca in Peru appear to be Aquitanian or Burdigalian in age, and a consideration of both classes of evidence leads to the conclusion that this flora and the associated fauna of the Heath stage are of Burdigalian age.

\section{Chile}

There are at least two Tertiary fossiliferous horizons in Chile. These are the Coquimbo beds and the Navidad beds. The former do not concern the present discussion, particularly since they are probably of Pliocene age and correspond to the Paita stage of Peru. The second, or Navidad, beds (localities 7 and 8 ) have an important bearing on the present discussion. They comprise prevailingly arenaceous deposits carrying locally an abundant marine fauna, and toward the base, according to Steinmann, coal beds and an associated terrestrial flora. While their areal distribution and stratigraphic or structural relations have never been described, they have been recognized at a number of scattered localities and there has been a tendency, exemplified by Möricke, to carry the name Navidad to more or less uncertain correlatives in other parts of South America. Along the west coast of Chile, however, at Navidad, Matanzas, Lebu, Coronel, Lota, Puchoco, Island of Chiloé, and elsewhere, they have been definitely recognized and they may extend as far southward as the Straits of Magellan.

The Navidad fauna, which is extensive, has been described principally by Philippi ${ }^{10}$ and Möricke. ${ }^{11}$ It shows closer relationships with the Tertiary faunas of Europe than with the corresponding faunas of Australia and New Zealand, although it contains some elements common to the latter. Engelhardt ${ }^{12}$ has described an extensive flora from the coal-bearing sandstones in the Navidad beds near Coronel. This flora consists of 94 species, well distributed among the natural orders and indicative of tropical humid conditions. It is of great interest, in that it contains a considerable element derived from the north and also found in the Eocene of southeastern North America. This element includes the genera Zamia, Anona, Myristica, and representatives of the families Papilionaceæ, Bombacaceæ, Dilleniaceæ, Lauraceæ, Myrtaceæ, Boraginaceæ, and Rubiaceæ. Compared with the known fossil floras from other parts of South Amer-

\footnotetext{
${ }^{10}$ R. A. Phllippl : Die tertiären und quartaren Versteinerungen Chiles. Lelpzig, 1887.

11 W. Möricke : Versteinerungen der Tertiärformation von Chile. Neues Jahrb. Bell., Bd. 10, 1896, pp. 548-612, pls. 11-13.

12 H. Engelhardt: Ueber Tertiärpflanzen von Chile. Abh. Senck. Naturf. Gesell., Bd. 16, hft. 4, 1891, pp. 629-692, pls. 1-14. Bemerkungen zu chilenischen Tertiärpflanzen. Abh. naturw. Gesell., Isis in Dresden, 1905, pp. 69-82, pl. 1.
} 
ica, the Navidad flora contains 3 species in common with that found in the Loja basin of Ecuador, 2 species in common with that found in $\mathrm{Co}$ lombia, and 2 species in common with that described recently from Peru. When compared, on the other hand, with the geographically mueh less remote flora found in the Magellanian beds along the straits of that name and on Tierra del Fuego, it is found to have nothing in common with the latter except a single species of Flabellaria, about which Dusén expresses the opinion that it could not have come from the Magellanian beds, and in this Dusén appears to be perfectly justified. It appears that the Navidad flora is younger than the floras known from farther south.

Before discussing the age of the Navidad beds, I wish to refer to the so-called Patagonian beds of southern Argentina, the marine fauna from which has been admirably described by Ortmann. ${ }^{13}$ This fauna has been satisfactorily shown to be of lower Miocene age, and while the Australian and New Zealand element is more pronounced than in the Navidad beds, nevertheless the Patagonian has, out of a total fauna of 151 species, 34 that are identical with and 15 additional that are closely allied with Navidad species. Ortmann quite rightly concludes that the Patagonian is synchronous with at least a part of the series referred to the Navidad.

In conformity with the conclusions of invertebrate paleontology as expressed by Steinmann, Möricke, Ortmann, and others, and from a consideration of the flora found in these beds, I would confirm the lower Miocene age of a part at least of what goes under the name of Navidad beds and I would consider them as representing the Burdigalian stage and possibly the older Aquitanian stage as well, since transgression was continuous in Europe from the one to the other as it was also in the Canal Zone. The presence of some of the mollusca of the Navidad beds in the Magellanian Oligocene may indicate that a part of the former is still older than Aquitanian, but this I greatly doubt, since the facts can be explained by intermigrations of the forms better than by postulating contemporaneity. The facies of the Navidad flora appears to be slightly older than the previously mentioned fossil floras from Colombia, Ecuador, and Peru, and it may well fall within the Aquitanian, but it is surely not so old as Eocene, as Steinmann and De Lapparent suggest, nor is it so old as the Fagus flora of the Straits of Magellan and Tierra del Fuego, which I have considered as Lower Oligocene in age.

Windhausen ${ }^{14}$ has recently described the hitherto unknown (wrongly

\footnotetext{
${ }^{13}$ A. W. Ortmann : Tertiary Invertebrates. Princeton Exped. to Patagonia, vol. 4, 1901-1906, pp. 45-332, pls. 11-39.

14 A. Windhausen: The problem of the Cretaceous-Tertiary. boundary in South America and the stratigraphic position of the San Jorge formation in Patagonia. Am. Jour. Sci. (iv), vol. 45, 1918, pp. 1-53.
} 
correlated) transgression of what he calls the San Jorge formation, which in the early Eocene flooded the east coast of southern Argentina and penetrated northwesterly up the Roca Valley. I mention this admirable contribution in the present connection, since it has a bearing on the age and antecedent history of the Magellanian beds.

At Punta Arenas and elsewhere along the Straits of Magellan and at various localities in Tierra del Fuego a series of sandy lignitic beds have been described by Ortmann, Hatcher, Nordenskjold, and others, which are of the greatest interest to paleobotanists because of the remarkable flora contained near their base. The section, somewhat abbreviated, is as follows :

1. Sands, lignitic sandstone, and conglomerates $=$ horizon $\mathrm{V}$ of Hatcher $=$ Patagonian formation of Ortmann $=$ Burdigalian.

2. Sandstones with lignite beds and fossil plants = horizon IV of Hatcher $=$ Upper lignites or Punta Arenas coal $=$ Miocene Araucaria beds of Dusén = Acquitanian.

3. Sandstone with oyster beds $=$ horizon III of Hatcher $=$ Oligocene.

4. Sandstones with fossiliferous calcareous lenses $=$ Oligocene.

5. Fossiliferous beds = horizon II of Hatcher = Oligocene.

6. Sand and sandstone with fossiliferous calcareous concretions and fossil plants $=$ horizon I of Hatcher $=$ Oligocene Fagus zone of Dusén $=$ Oligocene.

7. Iignitic shales $=$ Lower lignites of Hatcher $=$ Oligocene (?).

This section presents the record of a minor oscillation of the strandline with continental deposits passing into lagoonal, and these into littoral and-shallow-water marine, and then gradually shallowing and perhaps becoming emergent during the Aquitanian, followed by a marked transgression in the Burdigalian. At present our chief interest centers in the Fagus zone and its flora. This flora, as described by Dusén, ${ }^{15}$ consists of 29 species, of which the Flabellaria, previously mentioned as doubtful, is the only one that occurs in the Tertiary floras already enumerated from South America. The particular facies of this flora is furnished by the abundance of Fagacee. This family is represented by two species of Fagus and by 13 species or varieties of Nothofagus. This flora is certainly older than those already mentioned and it is as certainly Tertiary in age. It unquestionably had its beginnings in the Northern Hemisphere and has also been found to be represented at somewhat similar horizons in Australia, New Zealand, and Antarctica. That it did not migrate into Patagonia from North America appears to be probable from the absence of any definite ancestral assemblage in the abundantly fos-

\footnotetext{
${ }^{15}$ P. Dusén : Ueber die tertiüre Flora der Magellanslander. Svenska Exped. till Magellanslănderna, Band 1, 1899, pp. 87-107, pls. 8-13.
} 
siliferous Upper Cretaceous or Eocene of the latter continent from which it seems probable that it could have been derived. Nor are any traces of it found at more northern localities in South America. The explanation seems to be that it reached southern South America from the opposite direction, namely, Antarctica.

A very interesting Tertiary flora has been recently described ${ }^{18}$ from the border of the Antarctic continent on Seymour Island, off the east coast of Graham Land. This flora contains a large element of subtropical types like those found today in southern Brazil, and another large element of forms suggestive of the existing temperate fiora of southern Chile and Patagonia, and including species of Fagus and Nothofagus like those found in Patagonia, Chile, Australia, and New Zealand. Dusén, ignoring the usually mixed climatic character of early Tertiary floras, and the association of tropical and temperate types under favorable conditions of humidity, and basing his conclusions on the broken character of the fossil remains of these temperate types, reaches the conclusion that the temperate and the subtropical elements were contemporaneous, but that the latter were coastal forms under a subtropical climate, while the former grew in the vicinity at elevations which he suggests amounted to 6,500 feet or more, and were brought by streams to the littoral basin of sedimentation. If this is true, it indicates a considerable mountain chain of the Andean type forming the axis of Graham Land at that time as it does at present. The only evidence bearing on the age of the folding, which may really have little bearing on the time of elevation, is the presence at Hope Bay, on Graham Land, of an extensive late Jurassic flora ${ }^{17}$ found in continental beds which are involved in this folding. Dusén concludes that this Tertiary Antarctic flora is older than that of the Fagus zone of the Magellanian beds.

Poorly preserved mollusks associated with the plants are considered by Wilckens to represent what he calls the Patagonian molasses, but since the latter is more or less composite, as Windhausen ${ }^{18}$ has shown, and includes faunal elements belonging to the lower Eocene San Jorge formation as limited by the latter author, the evidence for the correlation adopted by Andersson ${ }^{19}$ can not be said to be conclusive. The presence of Zeuglodon vertebræ, described from this locality by Wiman, should probably be con-

\footnotetext{
${ }^{16}$ P. Dusen: tber die Tertiăre Flora der Seymour-Insel. Wiss. Ergeb. Schwed. Sidd. polar-Exped., Band 3, 1908, 27 pp., 4 pls.

${ }_{17}$ T. G. Halle: The Mesozolc flora of Graham Land. Swedish South Polar Exped., 1901-1903, Band 3, lief 4, 1913, 123 pp., 9 pls.

18 Op. cit.

$10 \mathrm{~J}$. Gunnar Andersson : On the geology of Graham Land. Bull. Geol. Inst. Upsala, vol. 7, 1906, pp. 19-71, pls. 1-6.
} 
sidered as evidence of Eocene age. I would therefore dissent from Wilcken's conclusions that this plant-bearing sandstone is Upper Oligocene or Lower Miocene in age and would consider this flora as of Middle or Upper Eocene age.

\section{SUMmarY}

Summarizing the foregoing brief notes and going beyond them into the Mesozoic in order to indicate land connections that were barriers to marine dispersal and avenues for the migration of terrestrial faunas and floras, it may be noted that South America and Antarctica were connected during the late Jurassic, and that this connection was not interrupted during the long ages of the Lower Cretaceous. At the other end of South America Panama appears to have been emerged throughout the Lower Cretaceous, but there was no direct connection between Antarctica and North America, unless it was over an Antillean land bridge, until near the end of the Lower Cretaceous, at which time a continuous land connection was established which continued with various modifications throughout the Upper Cretaceous.

During the Upper Cretaceous the world-wide Emscherian-Lower Aturian transgression is recorded in the Quiriquina beds of Chile, at various localities in Peru and Patagonia, and in the richly fossiliferous leposits of Graham Land, with their Indo-Pacific ammonite faunas. Although it was perhaps possible for these latter faunas to have invaded the margins of Graham Land from the east, it seems more probable, in view of the similarities of the fauna to that found in the Quiriquina beds of Chile, that the land connection with Antarctica which had persisted since Jurassic time was interrupted during the middle part of the Upper Cretaceous, at which time shallow marine waters permitted the invasion of the region by these ammonite faunas.

Toward the close of the Upper Cretaceous, however, and throughout all of southern and western South America, there is evidence that this Upper Cretaceous submergence was followed by a negative movement of the strand-line and emergence of the land. This occurred during the time interval of the Maestrichtian and Danian stages of the Upper Cretaceous and continued for a much longer time than this throughout most of South America. This late Upper Cretaceous emergence is shown by the absence of any known faunas representing these stages, by the lithologic indications in the higher levels of increasing shallowness of the waters, and by the continental variegated sandstones of this age in Patagonia. At this time, then, Antarctica was connected with Patagonia and the Isthmus of Panama was dry land. 
This emergent phase continued throughout nearly the whole of the Eocene, for while there was a local transgression from the East, represented by the San Jorge formation in Patagonia, this was not of sufficient magnitude to connect the waters of the Atlantic and the Pacific. There was thus afforded an opportunity for the flora of North America to invade South America at the beginning and toward the close of the Upper Cretaceous, already indicated by the presence of representatives of the Dakota sandstone flora in Argentina, ${ }^{20}$ and similar land connections were available throughout most of Eocene time. Similar opportunities for the interchange of terrestrial life, both animal and vegetable, between South America and Antarctica were also present during these same intervals.

During the Oligocene there is evidence of minor transgressions in Panama; on the Peruvian coast, where the Ovibio stage contains two or three marine forms but is mainly a littoral and continental flysch-like sandstone; in Patagonia, where the Magellanian beds contain oyster beds and a few other shallow-water marine forms between two lignitic horizons. This Oligocene emergence is marked in Chile and Graham Land, and by the continental Deseado formation (Notostylops, Pyrotherium beds) of Patagonia.

Toward the end of Oligocene time or the beginning of Lower Miocene (Aquitanian-Burdigalian stages) we everywhere find evidence of marked submergence. This is shown by the Culebra, Emperador (continental), and Gatun formations of Panama; by the Zorritos and Heath stages of Peru, and by the Navidad beds of southern Chilè. The faunas of these west coast beds are remarkable for the Caribbean and Mediterranean elements that they have furnished, thus affording collateral evidence of the free mingling of the waters of the Atlantic and the Pacific where the Isthmus of Panama now stands. Similar evidence of submergence is furnished by the marine Patagonian beds, whose fauna has been described by Ortmann, and possibly by a part of the younger Seymour Island beds of Andersson.

The upper Miocene is, so far as I know, a time of rather widespread emergence and land connections. No marine upper Miocene is known from Panama, Chile, Patagonia (continental Santa Cruz beds), or Antarctica. The Talara stage of Grzybowski in northern Peru is the only exception to this statement, and if it is correctly correlated it represents a very minor movement of the strand.

Following the widespread upper Miocene emergence, there is an equally widespread Pliocene submergence, illustrated by the Toro limestone of

${ }^{20} \mathrm{~F}$. Kurtz: Sobre la existencia de una Dakota-Flora en la Patagonia austro-occidental. Revista Museo de La Plata, vol. 10, 1899, pp. 43-60. 
Panama, the Paita stage of Peru, the Coquimbo and Caldera beds of Chile, the Parana beds of Patagonia, and the Pecten beds of Graham Land. It is also emphasized by the presence of a marine Pliocene fauna at elevations of over 13,000 feet in the eastern Andes of Bolivia. ${ }^{21}$ The subsequent history need not be discussed, although this widespread similarity of events continued throughout the coastal region down to the present.

This parallelism in the movements of the strand over so vast an area is so remarkable that $I$ have gathered together such information as is available in the accompanying table. While this is very incomplete, it seems worth presenting in tabular form and it will also serve as a graphic summary, without additional discussion, of the correlations that I have arrived at from a study of these various plant-bearing horizons and associated beds in South America.

${ }_{21}$ E. W. Berry : U. S. Natl. Mus., Proc., vol. 54, 1918, no. 2229. 
TIABULAR SUMMARY

\begin{tabular}{|c|c|c|c|c|c|c|c|c|}
\hline & Panama. & COLOMBIA. & ERCUADOR. & Peru. & Bolivis. & ChILE. & Patagonia. & Graham Land. \\
\hline Recent. & Fmergence. & Emergence. & Fmergence. & Emergence. & Emergence. & Emergence. & Nomergence. & Emergence. \\
\hline Late and post-Glaclal. & Submergence. & 8 & $?$ & $\begin{array}{l}\text { Submergence ("tablaza" } \\
\text { beds). }\end{array}$ & 3 & $\begin{array}{l}\text { Submergence. } \\
\text { Valparaiso stage. }\end{array}$ & Submergence. & Submergence. \\
\hline Glacial. & Emergence. & $?$ & $?$ & Emergence. & $?$ & Fmergence. & Emergence. & Fmergence. \\
\hline Pliocene. & Toro limestone. & $?$ & $?$ & Paita stage. & $\begin{array}{c}\text { Discinisca and plant } \\
\text { tuffs of Potosi } \\
\text { and Corocoro. }\end{array}$ & $\begin{array}{l}\text { Coguimbo and Cal- } \\
\text { dera beds. }\end{array}$ & Parana beds. & Pecten beds. \\
\hline Upper Mlocene. & Emergence. & Honda beds? & $?$ & Talara stage. & & Emergence. & $\begin{array}{l}\text { Emergence (Santa Cruz } \\
\text { beds). }\end{array}$ & Emergence. \\
\hline $\begin{array}{l}\text { Lower Miocene, Burdiga- } \\
\text { llan, and Aquitanian. }\end{array}$ & $\begin{array}{c}\text { Gatun formation, } \\
\text { perador limestone, } \\
\text { per Culebra. } \\
\text { Dep- } \\
\text { Dp- }\end{array}$ & $\begin{array}{l}\text { Andean plant beds. } \\
\text { Santa Ana. }\end{array}$ & $\begin{array}{l}\text { Andean plant beds. } \\
\text { Loja coal. }\end{array}$ & $\begin{array}{l}\text { Zorritos and Heath stages. } \\
\text { Fossil plants of Tumbez. }\end{array}$ & & $\begin{array}{l}\text { Navidad beds. } \\
\text { Fossll plants of } \\
\text { Coronel and Lota. }\end{array}$ & $\begin{array}{l}\text { Patagonian beds: } \\
\text { Punta Arenas coal (Arau- } \\
\text { caria). }\end{array}$ & $\begin{array}{l}\text { Possibly a part of the } \\
\text { younger Seymour Island } \\
\text { beds of Andersson. }\end{array}$ \\
\hline $\begin{array}{l}\text { oligocene, Chattian, Stam- } \\
\text { pian, Sannolsian. }\end{array}$ & $\begin{array}{l}\text { Lower Culebra, Tonosi } \\
\text { limestone, Bohlo con- } \\
\text { glomerate. } \\
\text { Tomerged? }\end{array}$ & & & $\begin{array}{l}\text { Oviblo stage, mainly con- } \\
\text { tinental sandstones. }\end{array}$ & & Emergence. & $\begin{array}{l}\text { Deseado (Notostylops and } \\
\text { 1yrotherlum beds). } \\
\text { Local submergence In the } \\
\text { Magellanian beds. } \\
\text { Fagus and lower lignite } \\
\text { beds. }\end{array}$ & Emergence. \\
\hline Docene. & $\begin{array}{l}\text { Transgression in Upper } \\
\text { Eocene. } \\
\text { Emergence. }\end{array}$ & & & Tmergence. & & Emergence. & $\begin{array}{l}\text { Emergence. } \\
\text { Local transgression of } \\
\text { San Jorge formation } \\
\text { (Roca beds). }\end{array}$ & $\begin{array}{l}\text { Littoral sediments with } \\
\text { fossil plants. } \\
\text { Emergence. }\end{array}$ \\
\hline$\left\{\begin{array}{c}\text { Danian and Maes- } \\
\text { trichtian. }\end{array}\right.$ & Emergence. & & & Dmergence. & & Emergence. & $\begin{array}{l}\text { Emergence with varle- } \\
\text { gated continental sand- } \\
\text { stones. }\end{array}$ & Emergence. \\
\hline $\begin{array}{l}\text { Campanian, Emsche- } \\
\text { rian, Turonian. }\end{array}$ & Emergence. & & & Sulomergence. ${ }^{23}$ & & Quiriquina stage. & Submergence. & $\begin{array}{l}\text { Rich Indo-Pacifle Ammo- } \\
\text { nIte faunas. }\end{array}$ \\
\hline Lower Cretaceous. & Emergence. & & & $\begin{array}{l}\text { Omergence. } \\
\text { rine beds } \approx \text { Local ma- } \\
\text { fora). }\end{array}$ & & Emergence. & $\begin{array}{c}\text { Emergence (local marine } \\
\text { beds). } .^{22}\end{array}$ & Emergence. \\
\hline
\end{tabular}

21 More or less contemporaneous.

Lered Letaceous, perhaps Aptian, on the Lago San Martin.

23 Neumann: Neues Jabrb. Bell., Bd. 24, 1907. 
